\title{
A CRITICAL REVIEW OF CORRUPTION COST FOR DEVELOPING COUNTRIES
}

\author{
Lavinia DUDAŞ \\ Lavinia MIHIT⿻コ一
}

\begin{abstract}
The research of corruption phenomenon has expanded in the economic literature. Corruption costs can be observed in different places, over time and affect especially the efficiency of governments and implicitly the economic growth of countries. Using content analysis, this paper focuses mainly on studies that are analyzing corruption in emerging countries and presents the main results of over 30 studies and also the research methodology. We observed that the empirical approach is more often used than the theoretical one. Furthermore, we discovered that corruption is associated with government failure, institutional weaknesses, electoral periods, low wages, a predominant share of men in parliament and government, the degree of press freedom and is affecting especially the economic growth, investment and FDI levels.
\end{abstract}

Keywords: corruption, developing countries, fiscal policy, content analysis

JEL codes: D73, E62, F62

\section{Introduction}

Although corruption has been around us in one form or another, maybe as old as the first organized societies, its consequences started to receive an increasing attention in the last three decades from academia and international organizations. Major scandals like Watergate, Enron, Lehman Brothers Bank have generated an increase in the anti-corruption legislation. We can add here the currency crises from Asia, Russia, Latin America from the late '90s that once again shows that an increased level of corruption (especially the improper distribution of financial resources to family and friends, required bribes to enter the market) reduces the international confidence (investors or creditors) and can generate extremely negative effects on the economy.

Corruption cost for the economic development of countries it can easily be observed throughout history, mentioning here as its effects the impossibility to sustain economic growth on long periods, the decrease in public investment but also in FDIs, lower public wages and in the end lower tax revenues. Friedman et al. (2000) showed that corrupt governments, in the end, will become small governments with fewer revenues from tax collection since the private sector will try to bypass the bureaucracy and tax payments, will uncorrupt governments, or relatively uncorrupt, can introduce higher taxes.

Starting from the ' $90 \mathrm{~s}$, major international institutions like the International Monetary Fund (IMF), World Bank (WB), European Commission have granted an increasing attention to corruption, by trying to assess it and fight it around the world. To this end, the latest measure was proposed in April 2018 by the IMF when they announced a new framework to assess weak governance and corruption in their member countries. Furthermore, the first assessment will begin

\footnotetext{
${ }^{1}$ Lecturer, PhD.,Faculty of Economic Sciences, Computer Science and Engineering, "VasileGoldis" Western University of Arad, Romania, Str.Liviu Rebreanu nr. 86, Arad, lavinia.mustea@gmail.com

${ }^{2} \mathrm{PhD}$. Student, Doctoral School of Economics and Business Administration, West University of Timișoara, Romania, Str. J.H.Pestalozzi, nr. 16, 300115 Timișoara, lavinia.mihit@gmail.com

DOI: 10.29302/oeconomica.2018.20.2.6
} 
with the G7 countries (Canada, France, Germany, Italy, Japan, United Kingdom and the United States) and Austria and the Czech Republic, that also volunteered.

Following Jain (2001), Aidt (2003) and Cintra et al. (2018) we present below important studies that investigated corruption effects in developing countries. Moreover, we develop the previous studies on the one hand, by revealing also the main findings besides the sample and methodology used and on the other hand, by focusing on studies that are investigating the macroeconomic impact of corruption, namely at country level, the public impact and less from companies' impact. We observed that there is an increase in published paper between 2000-2003 and 2017-2018 that are trying to discover the determinants of corruption and the costs for economies. To be more precise, the literature on this topic reveals that among the important factors that determine an increase in corruption acts are weak government institutions, excessive bureaucracy, electoral periods, average low wages, low press freedom and the low number of female.

The rest of the paper is structured as follows: Section 2 defines corruption and mentions the main used indices, Section 3 reveals the main findings in the literature analyzing corruption in developing countries and Section 4 Concludes.

\section{Defining and measuring corruption}

It is difficult to find a universally valid definition of corruption, essentially due to its multidimensional nature, meaning that it can take different connotations in different contexts. To establish a unique definition for corruption is impossible since the concept differs from country to country, in direct connection with the values, culture and history of the country and it also differs from organization to organization in relation to the field of interest.

The academia that focuses on analyzing corruption, but also international institutions and organizations that fights corruption defined corruption through time. Jain (2001) considers that corruption is the use of public office in order to obtain a personal gain, doing that by avoiding the rules. In accordance with the previous definition, Aidt (2003) divided corruption into four categories, namely "efficient corruption" when it's used to adjust government failures; "corruption with a benevolent principal" when the decision making is delegated; "corruption with a nonbenevolent principal" when government officials implement inefficient policies in order to obtain rents and "self-reinforcing corruption" that is encountered in countries that have a history of corruption acts.

A concise definition of corruption is given by the World Bank, respectively "the abuse of public office for private gain". The Bank pays a great attention to corruption since a major part of its activity is to support governments projects and policies and from experience, a negative impact was observed on the macroeconomic stability, foreign direct investments, small entrepreneurs, the environment and on people with lower incomes. The World Bank investigates bribery acts, thefts, political and bureaucratic corruption, isolated and systemic corruption and corruption in the private sector. From the United Nation (2004) point of view, corruption can be divided in "grand corruption" which is encountered in governments higher levels, "petty corruption" that refers to administrative corruption generally consisting of small favors and bribery. Furthermore, OECD (2008) defines corruption as the misuse of public official's power for private financial or other benefits while the European Commission (2003) and the IMF describes it as the abuse of public power for private gain.

The development of anti-corruption strategies and policies generated the need to construct measurement instruments through which corruption can be monitored across the world. To this end, the first indices that measure corruption where announced in 1995 by Transparency International, the Corruption Perception Index and in 1996 by the World Bank, Control of Corruption Indicator. In the same period, the European Union started to developed anti-corruption policies and in 1999 the Group of States against Corruption (GRECO, that currently has 49 member states) was founded 
in order to monitor the corruption level across member countries. Together with the development of anti-corruption policies, more indices and indicators were created in order to better capture the corruption level. Malito (2014) grouped the indices in three main categories: (i) corruption surveybased (e.g. Corruption Perception Indices, Corruption Experience Index), (ii) governance indices (e.g. Eurobarometer, World governance indicators) and (iii) state capacity indices (e.g. Index of State Weakness in the Developing World, LICUS). Furthermore, Hlatshwayo et al. (2018) classify corruptions-related measures in first, second and third generation measures of corruption as depicted in Figure 1. They explain that the first generation measures rely on people perception of corruption, the second generation rely on experienced corruption and bureaucratic quality indicators, while the third generation measures make use of big data.

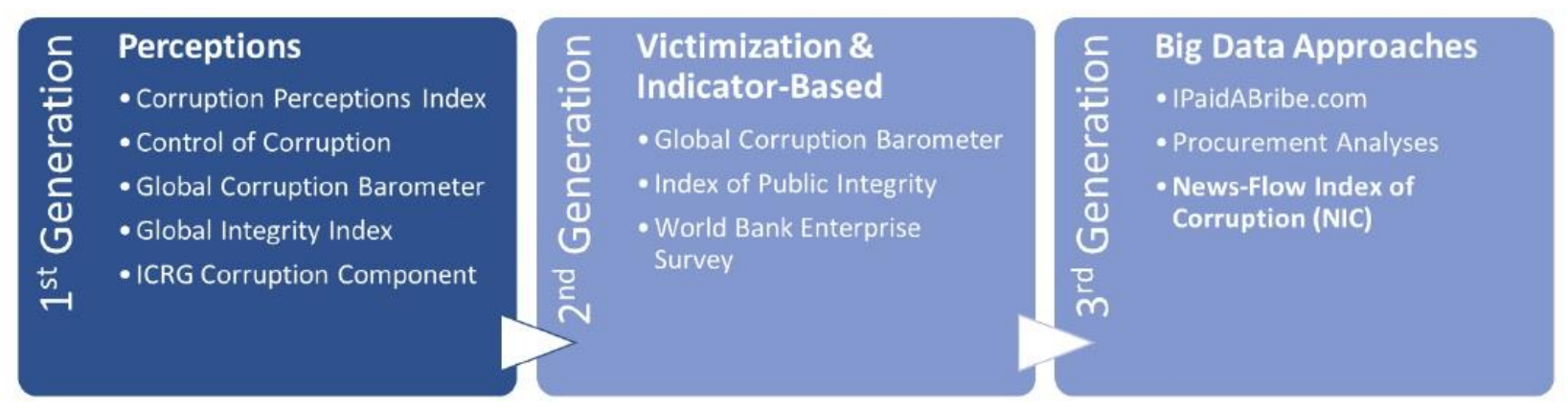

Figure 1. Corruption measurement. Source: Hlatshwayo et al. (2018), page 8

\section{Corruption cost in developing countries}

There is an extensive literature that has focused on measuring the corruption cost for the economy, especially the effect on issues like growth, foreign direct investments, public investment, human capital, education. Table 1 presents the main results from studies that are analyzing corruption in developing countries, or studies that have in their sample developed and developing countries but are also analyzing subsamples of developing countries. Moreover, the applied methodology in analyzing corruption is also mentioned.

Studies on corruption in developing countries

Table 1.

\begin{tabular}{|c|c|c|c|}
\hline Authors & Data & Method & Main results \\
\hline $\begin{array}{c}\text { Friedman et al. } \\
(2000)\end{array}$ & 69 countries & Regression & $\begin{array}{c}\text { Higher tax rates are related with less unofficial } \\
\text { activity from the private sector and corruption } \\
\text { is related to more unofficial activity. }\end{array}$ \\
\hline $\begin{array}{c}\text { Johnson et al. } \\
(2000)\end{array}$ & $\begin{array}{c}5 \text { Eastern } \\
\text { Europe countries }\end{array}$ & Regression & $\begin{array}{c}\text { Unofficial activity is larger in Russia and } \\
\text { Ukraine than in Poland, Slovakia and } \\
\text { Romania due to bureaucratic corruption. }\end{array}$ \\
\hline $\begin{array}{c}\text { Sandholtz and } \\
\text { Koetzle (2000) }\end{array}$ & 50 countries & $\begin{array}{c}\text { Multivariate } \\
\text { regression }\end{array}$ & $\begin{array}{c}\text { Corruption level is higher in countries with } \\
\text { lower average income, large state control of } \\
\text { the economy, weak institutions, low level of } \\
\text { integration in the world economy, low } \\
\text { Protestant population. }\end{array}$ \\
\hline $\begin{array}{c}\text { Treisman (2000) } \\
\text { Corruption } \\
\text { indexes } \\
\text { evaluation }\end{array}$ & Regression & $\begin{array}{c}\text { Statistically significance for lower corruption } \\
\text { if a country has Protestant history, British rule, } \\
\text { more developed and opened economies and a } \\
\text { longer democracy. Not significant was the } \\
\text { current degree of democracy }\end{array}$ \\
\hline Wei (2000) & 12 source & Ordinary & An increase in corruption or taxes in host \\
\hline
\end{tabular}




\begin{tabular}{|c|c|c|c|}
\hline & $\begin{array}{c}\text { countries of FDI } \\
\text { and } 45 \text { host } \\
\text { countries }\end{array}$ & $\begin{array}{l}\text { minimum } \\
\text { square, Tobit } \\
\text { estimation } \\
\end{array}$ & $\begin{array}{c}\text { countries generates a decrease in FDI. } \\
\text { American investors are especially hostile to } \\
\text { corruption. }\end{array}$ \\
\hline Jain (2001) & & $\begin{array}{l}\text { Literature } \\
\text { review }\end{array}$ & $\begin{array}{l}\text { Presents the factors that determine a decrease } \\
\text { in corruption levels, the methods used to } \\
\text { assess the impact of corruption and presents } \\
\text { future research. }\end{array}$ \\
\hline Mo (2001) & 46 countries & OLS & $\begin{array}{c}\text { A } 1 \% \text { increase in corruption reduce growth by } \\
0.72 \% \text { and the most important channel is } \\
\text { political instability. }\end{array}$ \\
\hline $\begin{array}{l}\text { Rijckeghem and } \\
\text { Weder (2001) }\end{array}$ & 31 countries & Regression & $\begin{array}{c}\text { Only a large increase in civil-service and } \\
\text { manufacturing wages can reduce the } \\
\text { corruption level. }\end{array}$ \\
\hline $\begin{array}{l}\text { Swamy et al. } \\
\qquad(2001)\end{array}$ & 45 countries & Probit regression & $\begin{array}{l}\text { Corruption is weaker when the women obtain } \\
\text { the majority of parliamentary seats and } \\
\text { positions in government. }\end{array}$ \\
\hline $\begin{array}{l}\text { Edison et al. } \\
\qquad(2002)\end{array}$ & 57 countries & $\begin{array}{c}\text { OLS } \\
\text { Two-stages least } \\
\text { square }\end{array}$ & $\begin{array}{c}\text { Economic growth is not statistically } \\
\text { significantly influenced by international } \\
\text { financial integration, even when controlled for } \\
\text { government corruption. }\end{array}$ \\
\hline $\begin{array}{l}\text { Fisman and Gatti } \\
(2002)\end{array}$ & 59 countries & Regression & $\begin{array}{c}\text { Fiscal decentralization in government } \\
\text { expenditure generates lower corruption. }\end{array}$ \\
\hline Paldam (2002) & 100 countries & Regression & $\begin{array}{l}\text { The determinants of corruption by the } \\
\text { importance of their effects are: GDP per } \\
\text { capita, the transition to a prosperous country, } \\
\text { increased regulation, inflation, and culture. }\end{array}$ \\
\hline Wei (2002) & $\begin{array}{l}1 \text { country - } \\
\text { China }\end{array}$ & Regression & $\begin{array}{c}\text { In a capital importing country, if corruption is } \\
\text { present, the FDI share in inflows will decrease } \\
\text { while the share of loans from foreign banks } \\
\text { will increase. }\end{array}$ \\
\hline Aidt (2003) & & $\begin{array}{l}\text { Literature } \\
\text { review }\end{array}$ & $\begin{array}{c}\text { Corruption and economic policies are } \\
\text { influenced by institutions and a country's } \\
\text { history. }\end{array}$ \\
\hline $\begin{array}{l}\text { Anderson and } \\
\text { Tverdova (2003) }\end{array}$ & 16 countries & $\begin{array}{l}\text { Multivariate } \\
\text { analysis }\end{array}$ & $\begin{array}{l}\text { Higher levels of corruption generate a higher } \\
\text { negative evaluation of political performance } \\
\text { and lower trust in government. }\end{array}$ \\
\hline $\begin{array}{c}\text { Brunetti and } \\
\text { Weder (2003) }\end{array}$ & 125 countries & Regression & $\begin{array}{l}\text { A high press freedom in one country will } \\
\text { generate a decrease in the corruption level. }\end{array}$ \\
\hline $\begin{array}{l}\text { Persson et al. } \\
\quad \text { (2003) }\end{array}$ & 80 countries & Regression & $\begin{array}{l}\text { The electoral system is positively linked to an } \\
\text { increase in corruption, mainly when there is a } \\
\text { larger number of candidates elected from the } \\
\text { party list. }\end{array}$ \\
\hline $\begin{array}{l}\text { Bräutigam and } \\
\text { Knack (2004) }\end{array}$ & 32 countries & Regression & $\begin{array}{l}\text { Good governance impacts the growth, mainly } \\
\text { through high aid levels in African countries }\end{array}$ \\
\hline Dinç (2005) & 36 countries & Regression & $\begin{array}{l}\text { Banks owned by the government increase the } \\
\text { lending by } 11 \% \text { in electoral years compared to } \\
\text { private banks. }\end{array}$ \\
\hline $\begin{array}{l}\text { Jong-Sung and } \\
\text { Khagram (2005) }\end{array}$ & 129 countries & $\begin{array}{c}\text { Analysis of } \\
\text { variance and } \\
\text { Regression }\end{array}$ & $\begin{array}{c}\text { Income inequality generates an increase in } \\
\text { corruption, along with economic development } \\
\text { and democracy }\end{array}$ \\
\hline
\end{tabular}




\begin{tabular}{|c|c|c|c|}
\hline $\begin{array}{c}\text { Kunicová and } \\
\text { Rose-Ackerman } \\
(2005)\end{array}$ & 124 countries & Regression & $\begin{array}{l}\text { Proportional representation systems generate } \\
\text { more corruption than plurality systems. }\end{array}$ \\
\hline $\begin{array}{c}\text { Busse and } \\
\text { Hefeker (2007) }\end{array}$ & 83 countries & Regression & $\begin{array}{l}\text { FDI's inflow is influenced by government } \\
\text { stability - conflicts, corruption, laws, } \\
\text { democratic accountability and the quality of } \\
\text { bureaucracy. }\end{array}$ \\
\hline $\begin{array}{l}\text { Ferraz and Finan } \\
\text { (2008) }\end{array}$ & $\begin{array}{c}1 \text { country - } \\
\text { Brazil }(373 \\
\text { municipalities }) \\
\end{array}$ & Regression & $\begin{array}{l}\text { The political selection appears if citizens are } \\
\text { informed about the corruption in the district. }\end{array}$ \\
\hline $\begin{array}{l}\text { Berdiev et al. } \\
\quad(2013)\end{array}$ & 111 countries & Regression & $\begin{array}{c}\text { Remittances determine an increase in } \\
\text { corruption level, especially in non OECD } \\
\text { countries. }\end{array}$ \\
\hline $\begin{array}{l}\text { Vladamannati } \\
\text { (2015) }\end{array}$ & India -30 states & Regression & $\begin{array}{c}\text { Scheduled election are linked to an increase in } \\
\text { registered corruption cases. }\end{array}$ \\
\hline D'Agostino(2016) & $\begin{array}{l}48 \text { African } \\
\text { countries }\end{array}$ & $\begin{array}{l}\text { Endogenous } \\
\text { growth model }\end{array}$ & $\begin{array}{l}\text { Corruption and especially military spending } \\
\text { have a negative effect on economic growth. }\end{array}$ \\
\hline $\begin{array}{c}\text { Menard and Weill } \\
(2016)\end{array}$ & 71 countries & GMM model & $\begin{array}{l}\text { They found no significant causal relationship } \\
\text { between aid and corruption. }\end{array}$ \\
\hline $\begin{array}{l}\text { An and Kweon } \\
\quad(2017)\end{array}$ & 129 countries & $\begin{array}{l}\text { Dynamic } \\
\text { principal -agent } \\
\text { model }\end{array}$ & $\begin{array}{l}\text { A } 1 \text { unit increase in the public wages will } \\
\text { decrease corruption by } 0.26 \text { units. This } \\
\text { relationship is especially significant in non- } \\
\text { OECD countries. }\end{array}$ \\
\hline Dutta et al. (2017) & 107 countries & GMM model & $\begin{array}{l}\text { Human capital has no impact on FDI inflows } \\
\text { even in countries with a high level of } \\
\text { corruption. Thus, countries with lower } \\
\text { corruption show an increase in human capital } \\
\text { accumulation. }\end{array}$ \\
\hline Kanyam (2017) & $\begin{array}{l}\text { 44 Sub-Saharan } \\
\text { African } \\
\text { countries }\end{array}$ & $\begin{array}{l}\text { Regression } \\
\text { GMM model }\end{array}$ & $\begin{array}{l}\text { Mobile phone and internet are strong factors } \\
\text { that determine a decrease in corruption level, } \\
\text { while government effectiveness and the rule of } \\
\text { law are negatively correlated with corruption. }\end{array}$ \\
\hline $\begin{array}{l}\text { Cintra et al. } \\
\qquad(2018)\end{array}$ & & $\begin{array}{l}\text { Literature } \\
\text { review }\end{array}$ & $\begin{array}{l}\text { three important periods: } 2000-2002 \text { focusing } \\
\text { of corruption in emerging markets, 2003-2005 } \\
\text { with a theoretical basis and 2006-2010 when } \\
\text { the discussion reached theoretical maturity. }\end{array}$ \\
\hline $\begin{array}{l}\text { Cooray and } \\
\text { Dzhumashev } \\
\quad(2018)\end{array}$ & 132 countries & $\begin{array}{l}\text { Theoretical } \\
\text { model }\end{array}$ & $\begin{array}{l}\text { Corruption has a negative impact (statistically } \\
\text { significant) on labour force participation rate } \\
\text { and employment rate. Higher wages, } \\
\text { regulatory quality and increase in } \\
\text { consumption tend to reduce the negative } \\
\text { impact of corruption. }\end{array}$ \\
\hline $\begin{array}{l}\text { Duerrenberger } \\
\text { and Warning } \\
\qquad(2018)\end{array}$ & 88 countries & Regression & $\begin{array}{l}\text { In countries with a lower level of corruption } \\
\text { the expected years of schooling in public } \\
\text { higher education increases and decreases in } \\
\text { countries with higher corruption. }\end{array}$ \\
\hline Lim (2018) & $\begin{array}{l}\text { A middle- } \\
\text { income African } \\
\text { Economy with } \\
\text { high corruption }\end{array}$ & $\begin{array}{l}\text { Endogenous } \\
\text { growth model }\end{array}$ & $\begin{array}{l}\text { Public infrastructure investments have no } \\
\text { important impact on increasing economic } \\
\text { growth, only anti-corruption policies. }\end{array}$ \\
\hline
\end{tabular}




\begin{tabular}{|c|c|c|c|}
\hline & level & & \\
\hline Sulemana (2018) & $\begin{array}{c}48 \text { Sub-Saharan } \\
\text { African } \\
\text { countries } \\
\end{array}$ & OLS & $\begin{array}{c}\text { Higher levels of income inequalities are linked } \\
\text { with lower levels of corruption. }\end{array}$ \\
\hline Uberti (2018) & $\begin{array}{c}64 \text { countries } \\
\text { Eastern Europe } \\
\text { and MENA }\end{array}$ & Regression & $\begin{array}{c}\text { The evidence show that corruption in Eastern } \\
\text { Europe, Central Asia and Balkans is only } 1 / 3 \\
\text { influenced by the by the Ottoman and socialist } \\
\text { rule and more by the economic under- } \\
\text { development. }\end{array}$ \\
\hline
\end{tabular}

Source: authors compilation based on abov- mentioned studies

\section{Conclusion}

The corruption phenomena probably appeared with the first organized society and evolved hand in hand in time. Law regulation regarding corruption started to intensify during the " $70 \mathrm{~s}$ and continues nowadays. Major international institutions like IMF, World Bank, GRECO recognized the negative effects on countries economy and started the assessment of corruption level by developing indices and indicators, but also established measures to fight against it.

After reviewing the literature on corruption in developing countries, we observed two periods when academia has granted an increased attention to this topic. The first period is between 2000-2003, while the second starts in 2017 and still continues. Furthermore, empirical approaches are more often used is investigating the corruption impact than the theoretical ones. Moreover, the main findings suggest that corruption can be associated with government failure, institutional weaknesses, political influence and electoral periods, low average wage, a predominant share of men in parliament and government, the degree of press freedom, even with the possibility to make use or not of mobile phones and the internet. The major costs of corruption are revealed to be the impossibility to maintain economic growth, the decrease in public investment, but also in foreign direct investment, and more importantly the people trust in government.

\section{Acknowledgments}

This work was supported by a grant of Ministery of Research and Innovation, CNCS UEFISCDI, project number PN-III-P1-1.1-PD-2016-0780, within PNCDI III. Lavinia Dudaş acknowledges the financial support.

\section{References}

1. Aidt, T., 2003. Economic Analysis of Corruption: A Survey, The Economic Journal, Vol.113, No. $491,632-652$.

2. An W., Kweon Y., 2017. Do higher government wages induce less corruption? Cross-country panel evidence. Journal of Policy Modeling 39, 809-826.

3. Anderson, C.J., Tverdova, Y.V., 2003. Corruption, political allegiances, and attitudes toward government in contemporary democracies. American Journal Political Science 47 (1), 91-109.

4. Berdiev, A.N., Kim Y., Chang C-P., 2013. Remittances and corruption. Economics Letters 118, 182-185.

5. Bräutigam, D.A., Knack, S., 2004. Foreign aid, institutions, and governance in Sub-Saharan Africa. Economic Development and Cultural Change 52 (2), 255-285.

6. Brunetti, A., Weder, B., 2003. A free press is bad news for corruption. Journal of Public Economics 87 (7-8), 1801-1824.

7. Busse, M., Hefeker, C., 2007. Political risk, institutions and foreign direct investment. European Journal of Political Economy 23 (2), 397-415.

8. Cintra R.F, Cassol A., Ribeiro I. Corruption and emerging markets: Systematic review of the most cited. International Business and Finance 45 (2018) 607-619. 
9. Cooray A., Dzhumashev R., 2018. The effect of corruption on labour market outcomes. Economic Modelling 74, 207-218.

10. D'Agostino G., Dunne J.P., Pieroni L., 2016. Corruption and growth in Africa. European Journal of Political Economy 43, 71-88.

11. Dinç, I.S., 2005. Politicians and banks: political influences on government-owned banks in emerging markets. Journal of Financial Economics 77 (2), 453-479.

12. Duerrenberger N., Warning S., 2018. Corruption and education in developing countries: The role of public vs. private funding of higher education. International Journal of Educational Development 62, 217-225.

13. Dutta N., Kar S., Saha S., 2017. Human capital and FDI: How does corruption affect the relationship? Economic Analysis and Policy 56, 126-134.

14. Edison, H.J., Levine, R., Ricci, L., Slok, T., 2002. International financial integration and economic growth. Journal of International Money and Finance 21 (6), pp. 749-776.

15. European Commission. 2003. Communication from the Commission to the Council, the European Parliament and the European Economic and Social Committee - On a comprehensive EU policy against corruption (COM(2003) 317 final - Not published in the Official Journal). Available at https://eur-lex.europa.eu/legal-content/EN/TXT/?uri=CELEX:52003DC0317.

16. Ferraz, C., Finan, F., 2008. Exposing corrupt politicians: the effects of Brazil's publicly released audits on electoral outcomes. The Quarterly Journal of Economics 123 (2), pp. 703745.

17. Fisman, R., Gatti, R., 2002. Decentralization and corruption: evidence across countries. Journal of Public Economics 83, pp. 325-345.

18. Friedman, E., Johnson, S., Kaufmann, D., Zoido-Lobaton, P., 2000. Dodging the grabbing hand: the determinants of unofficial activity in 69 countries. Journal of Public Economics 76 (3), 459-493.

19. Hlatshwayo S., Oeking A., Ghazanchyan M., Corvino D., Shukla A., Leigh L., 2018. The Measurement and Macro-Relevance of Corruption: A Big Data Approach. International Monetary Fund working Paper 18/195, p. 72.

20. Jain, A.K., 2001. Corruption: a review. Journal of Economic Surveys 15 (1), 71-121.

21. Johnson, S., Kaufmann, D., McMillan, J., Woodruff, C., 2000. Why do firms hide? Bribes and unofficial activity after communism. Journal of Public Economics 76 (3), 495-520.

22. Jong-Sung, Y., Khagram, S., 2005. A comparative study of inequality and corruption. American Sociological Review 70 (1), 136-157.

23. Kanyam D. A., Kostandini G., Ferreira S., 2017. The Mobile Phone Revolution: Have Mobile Phones and the Internet Reduced Corruption in Sub-Saharan Africa? World Development 99, 271-284.

24. Kunicová, J., Rose-Ackerman, S., 2005. Electoral rules and constitutional structures as constraints on corruption. British Journal of Political Science 35 (4), 573-606.

25. Lim, K.Y., 2018. Modelling the dynamics of corruption and unemployment with heterogeneous labour, Economic Modelling.

26. Malito D. V., 2014. Measuring Corruption Indicators and Indices. Robert Schuman Centre for Advanced Studies working Paper 2014/13 ,34p.

27. Menard A-R.,Weil L. 2016. Understanding the link between aid and corruption: A causality analysis. Economic Systems 40, 260-272.

28. Mo, P.H., 2001. Corruption and economic growth. Journal of Comparative Economics 29 (1), 66-79.

29. OECD. (2008). OECD Glossary of StatisticalTerms. OECD Publishing.

30. Paldam, M., 2002. The cross-country pattern of corruption: economics, culture and the seesaw dynamics. European Journal of Political Economy 18 (2), 215-240. 
31. Persson, T., Tabellini, G., Trebbi, F., 2003. Electoral rules and corruption. Journal of the European Economic Association 1 (4), 958-989.

32. Rijckeghem, C.V., Weder, B., 2001. Bureaucratic corruption and the rate of temptation: do wage in the civil service affect corruption, and by how much? Journal of Development Economics 65 (2), 307-331.

33. Sandholtz, W., Koetzle, W., 2000. Accounting for corruption: economic, structure, democracy, and trade. International Studies Quarterly 44 (1), 31-50.

34. Sulemana I., Kpienbaareh D., 2018. An empirical examination of the relationship between income inequality and corruption in Africa. Economic Analysis and Policy.

35. Swamy, A., Knack, S., Lee, Y., Azfar, O., 2001. Gender and corruption. Journal of Development Economics 64 (1), 25-55.

36. Transparency International, 2013. Website. Available at: https://www.transparency.org/

37. The World Bank. 1997. World Development Report. The International Bank for Reconstruction and Development. The Word Bank.

38. Treisman, D., 2000. The causes of corruption: a cross-national study. Journal of Public Economics 76 (3), 399-457.

39. Uberti L. J., 2018. Corruption in transition economies: Socialist, Ottoman or structural? Economic Systems.

40. United Nations 2004. United Nations Handbook on Practical Anti-Corruption Measures for Prosecutors and Investigators. United Nations.

41. Vadlamannati K. C., 2015, Fighting corruption or elections? The politics of anti-corruption policies in India: A subnational study. Journal of Comparative Economics 43 (4), 1035-1052.

42. Wei, S.J. a., 2000a. How taxing is corruption on international investors? The Review of Economics and Statistics 82 (1), 1-11.

43. Wei, S.J., 2000b. Local corruption and global capital flows. Brookings Papers on Economic Activity 2 (2), 303-346.

44. https://www.coe.int/en/web/greco last access 21september 2018.

45. https://data.worldbank.org/indicator/IQ.CPA.TRAN.XQ?fbclid=IwAR3nQf78hOmdxN2LhWJMugid2zXYhZ8AhCGnFf5DIkJbGFBdO4Iaa60Bf0 last access 5 octomber 2018. 